\title{
Reforming Refugee Healthcare in Canada: Exploring the Use of Policy Tools
}

\section{Réforme des services de santé pour les réfugiés au Canada : examen de l'utilisation des outils stratégiques}

\author{
शुำ \\ ETHAN HOLTZER, MHSC \\ Director of Operations and Quality, Dialysis Management Clinics \\ Markham, ON \\ ALICIA MOORE-DEAN, MSC(OT), MHSC \\ Manager of Medical Affairs and Governance Effectiveness \\ West Park Healthcare Centre \\ Toronto, ON \\ AMIRRTHA SRIKANTHAN, MD \\ Medical Oncologist, BC Cancer Agency \\ Clinical Assistant Professor, Department of Medical Oncology \\ University of British Columbia \\ Vancouver, BC \\ KERRY KULUSKI, MSW, PHD \\ Scientist, Lunenfeld-Tanenbaum Research Institute, Sinai Health System \\ Assistant Professor, Institute of Health Policy, Management and Evaluation \\ University of Toronto \\ Toronto, ON
}

\begin{abstract}
Refugee healthcare in Canada has been a controversial and heavily debated topic over the past several years. In this paper, we present a policy analysis of the 2012 Canadian federal government decision to change the criteria and funding of the Interim Federal Health Program (IFHP). The IFHP provides federally funded healthcare coverage for refugees until they gain access to provincially funded health insurance. The paper offers a policy
\end{abstract}


perspective on the changes to refugee health coverage over time. We draw on the policy concepts of agenda setting, framing, venues and causal stories to explore this topic. We suggest that these concepts represent a set of tools for both researchers and laypersons to critically appraise any issue on the policy agenda, and understand how certain topics become policy issues and why they are "solved" in particular ways.

\section{Résumé}

Les services de santé pour les réfugiés au Canada constituent un vif sujet de controverse et de débat depuis quelques années. Dans cet article, nous présentons une analyse politique de la décision prise en 2012 par le gouvernement fédéral, visant un changement des critères et du financement du Programme fédéral de santé intérimaire (PFSI). Le PFSI offre aux réfugiés une protection en matière de soins de santé jusqu'à ce qu'ils obtiennent accès aux services de santé provinciaux. L'article propose un point de vue politique sur les changements dans la protection en matière de santé pour les réfugiés au cours du temps. Pour étudier ce sujet, nous nous appuyons sur les concepts de mise à l'agenda, de formulation, de lieu et d'anecdotes. Nous suggérons que ces concepts représentent un ensemble d'outils, pour les chercheurs ou autres, leur permettant d'évaluer de façon critique tout enjeu qui figure à l'ordre du jour politique, notamment la façon dont certain sujets deviennent des enjeux politiques et pourquoi ils sont « réglés » d’une façon particulière.

\section{Introduction}

The number of refugees accepted into Canada fluctuates considerably, with numbers peaking to 25,356 in 2011 and dropping to 10,424 in 2013 (Government of Canada 2016). The cost to support these refugees also fluctuates. In 2010-2011, \$84.6 million was spent on the Interim Federal Health Program (IFHP) (Government of Canada 2012a). The IFHP ensured these refugees had health support similar to provincial and territorial plans and, in some cases, additional dental, drug and vision care services (Barnes 2012). From 2009 to 2012, the Conservative Canadian Federal Government's framing of Tamil and Roma refugees began to shift the discussion on the IFHP. Changes soon followed to the IFHP such that refugees were placed into categories that either resulted in a reduction of coverage or eliminated coverage all together (Barnes 2012). The IFHP policy change initially developed within a larger federal immigration reform, intent on improving security, and then shifted to a provincial healthcare arena. To understand these changes, it is important to recognize that policy making and policy decisions are often highly political.

Policy concepts are needed to understand the policy process by which decisions were actually made. Some of these include agenda setting, framing, venues and causal stories. In this paper, these concepts are applied to the topic of refugee healthcare policy reform in Canada. Next, the events and policy decisions that contributed to refugee health policy changes are outlined chronologically. Lastly, the paper reviews the implications of these policy concepts in influencing refugee healthcare policy. 


\section{Policy Concepts: Agenda Setting, Venues, Causal Stories and Framing} Agenda setting is a strategy that places issues at the forefront of public attention before instituting policy changes. It is commonly supported through the use of media to portray images and messages that shape public perception of important issues. Agenda setting serves as an important tool for political actors and parties, to first craft an agenda designed to place certain issues at the centre of political attention before making significant policy decisions (Green-Pedersen and Walgrave 2014). Once placed on the policy agenda, venues are strategically selected to increase buy-in from the public or special interest groups, to fuel policy change or policy adoption (Crynes 1998). Venues are the "institutional locations where authoritative decisions are made concerning a given issue - they are the locations at which policies originate, obtain support and are adopted as binding decisions" (Jordan and Turnpenny 2015). For example, the legal system represents a venue for evaluating the issues that ultimately affect the fundamental rights and freedom of the citizens. Framing and causal stories are used throughout the stages of policy initiation, development and implementation. A causal story is defined as the process by which problems are represented through images and transformed into stories that assign cause, blame and responsibility (Stone 1989). Framing is a way of describing the policy to influence understanding and rationale behind reform, or essentially a way in which policy actors help people understand core issues. For example, framing is on display during the question period at the House of Parliament, where each political party presents issues through the beliefs and values of their party.

\section{Agenda Setting: Formation}

In 2009, the MV Ocean Lady arrived on the coast of Vancouver, British Columbia, Canada, carrying 76 Tamil asylum-seeking refugees. The arrival of the Ocean Lady triggered the enactment of the Balanced Refugee Reform Act in 2010, which included measures to strengthen the immigration system by reducing identity fraud through the use of biometric data such as fingerprints and photos. The arrival of the MV Sun Sea boat one year later carrying 500 additional Tamil asylum-seeking refugees sparked additional debate and a window of opportunity for the former federal government to add further legislative changes. Politicians began by re-framing public perceptions of refugees. They prompted discussions about the risk of "human smugglers" or "terrorists" among the asylum-seekers, bringing forward debates about the risks to national security and border safety. In this context, Canada was perceived as being an excessively generous humanitarian country. Prime Minister Stephen Harper spoke about the MV Sun Sea Incident during a 2010 federal election campaign:

"We will not hesitate to strengthen the laws if we have to, because ultimately as a government, we're responsible," Harper said. "It's a fundamental exercise of sovereignty, and we're responsible for the security of our borders and the ability to welcome people or not welcome people when they come" (CBC 2010). 
Here, the former Prime Minister, Stephen Harper, reframed the image of refugees through the lens of smuggling as opposed to a lens of freedom, which helped set the agenda for future legislative reform. The choice to situate the stories of the MV Ocean Lady and Sun Sea in the media has influenced the public's perception of the issue and its importance. This approach is well aligned with the agenda-setting theory, which describes the "ability [of the news media] to influence the salience of topics on the public agenda" (McCombs and Reynolds 2002).

The reframing of refugees (from freedom-seeking to smuggling) begins to draw a causal story by linking the event with the possibility that human intervention (i.e., government response) could render the issue avoidable in the immediate future. As a result, the Protecting Canada's Immigration System Act was introduced in 2012 as a credible government response to the issue of human smuggling. The Act was sponsored by Jason Kenney, the Conservative Minister of Citizenship, Immigration and Multiculturalism, and approved by the Conservative federal government. Areas of change to this federal immigration and citizenship legislation included an amendment of the safe countries of origin list. This list labelled people from certain countries ineligible for particular rights including the right to an appeal or compassionate and humanitarian considerations (Government of Canada 2012b). Government media releases presented the reforms as necessary to "crack down on human smuggling" (Government of Canada 2012c). The releases ran in contrast to how former refugees have been presented by the government, as people seeking freedom from oppression. For example, in July of 1979, Canada admitted 60,000 Vietnamese refugees, and since 2015, 30 April will be known as Journey to Freedom Day, a day to commemorate the journey of these refugees (Citizenship and Immigration Canada 2015).

\section{Cracking down on Human Smuggling: Implications for Refugee Healthcare} The IFHP has been the federal program that funds refugee healthcare in Canada since 1957 (Government of Canada 2015). Refugees are one of the few groups that fall under the federal healthcare jurisdiction, as the majority of Canadians receive their healthcare under provincial jurisdiction. Cracking down on human smuggling had multiple legislative implications, one of which included reforms to the IFHP. Reforms to the IFHP were driven by Jason Kenney, who framed the funding program as offering "gold-plated healthcare benefits that are better than those Canadian taxpayers receive" (Wherry 2012). Kenney suggested that these benefits led to "the abuse of Canada's overburdened healthcare system by bogus refugees" (Parry 2015). In support of this point, Kenney drew on examples of Hungarian Roma refugees. The former government did not view refugee claimants from Hungary as having a legitimate claim of persecution and felt that they posed an unnecessary burden on social services. Kenney's development of the term "bogus" refugee was described during a speech in 2012 in which he stated:

"Almost none of these European asylum claimants even show up for their hearings

- they just overwhelmingly abandon them and withdraw their own claims ... 
but they all do show up in Ontario's welfare program" Jason Kenney, Minister of Citizenship and Immigration (Boesveld 2015).

The federal government openly stated that refugee claimants from European states did not have legitimate claims of persecution. These claims were further advanced by a controversial report released by the Canadian Border Services Agency alleging a criminal element and fraudulent undertone amongst Roma refugee claimants (Canadian Border Services Agency 2012). The report outlined the surprisingly large increase in Hungarian refugee claimants from 2009 to 2011, and their high failure rate of acceptance (Canadian Border Services Agency 2012). A retrospective report provided evidence to suggest that Kenney and his government misrepresented Roma refugees. A review by professors at Osgoode Law School noted that anti-refugee rhetoric, institutional bias and quality of council issues compromised the claimant process for Roma refugees (Beaudoin et al. 2015). Nonetheless, the negative rhetoric continued. Kenney presented the issue of bogus refugees by repeatedly referencing the case of Hungarian Roma's refugees and their country of origin. The story tied into the former federal government's announcement of the designated countries of origin list, such that Hungary was one of the countries designated as "safe." The asylum-seeking process for Hungarians would prove more challenging and illustrated a binary construction of "bogus" versus "legitimate" refugees. Kenney established a powerful narrative and moral theory that all failed refugee claimants were bogus claimants seeking to manipulate the system. Reference to asylum-seekers - the status individuals are assigned before having a refugee claim determined (United Nations High Commission for Refugees 2015) - was not specifically addressed. Instead of excluding asylum-seekers from this definition, they were considered as a subset of "bogus refugees." Included in the public debate at the time were accusations that asylumseekers were "queue jumpers," further constructing "legitimate refugees" as individuals living in refugee camps near conflict zones and "bogus refugees" as anyone else, including those seeking protection within Canada. Cuts to the IFHP were cited as impacting only failed refugee claimants even though it also impacted all refugee claimants, including those in the process of seeking asylum. The policy change underestimated the genuine sense of fear experienced by refugees who felt that they could not return to their country. Some of these refugees had failed claims for a variety of reasons, none of which could be used to categorize them as bogus. A shift in discussion from supporting asylum-seekers to addressing bogus refugees refocused the issue. When the IFHP cuts were sold to the public as affecting failed (or bogus) refugee claimants, this vilified failed refugee claimants and garnered support for IFHP cuts to "save the taxpayer money." It established an arena of policy authority for the former government to legislate top-down reforms to the IFHP. These reforms are best described as top-down because implementation of the revised policy involved minimal public, intergovernmental or front-line worker engagement (Bowman 2014).

\section{Refugee Health Cuts: The Outcome}

Many healthcare workers tasked to implement the reforms to refugee healthcare vocalized and organized public opposition. Organizations representing various front-line workers, such 
as physicians, nurses, pharmacists and social workers, were among those engaging in direct and indirect action. Media releases, protests, political office sit-ins and refusals to cooperate were a few of the many actions that began to challenge the conditions necessary for successful top-down policy implementation (Bay Observer Staff 2015). A clear gap began to take shape between the original policy intent and the outcome after implementation. As predicted by Dr. Jeff Poston of the Canadian Pharmacists Association, the IFHP reforms were "going to result in costs downloaded to other jurisdictions" (Keung 2012). This cost download fell onto provinces, as healthcare providers carry a legal and ethical responsibility to treat patients in emergencies. When a patient is unable to pay either privately or through government insurance, the costs of care are often assumed by the provider or the province. Organizations like the University Health Network in Toronto, Ontario, had unpaid service debt balloon to upwards of $\$ 800,000$ per year because of the IFHP reforms (Keung 2013). Pressure from front-line workers eventually resulted in a change in venue. Although the refugee healthcare policy was originally revised through the venue of the federal legislature as an immigration policy, increasing front-line worker mobilization resulted in a shift to provincial jurisdiction, as a healthcare policy. Provincial governments soon began implementing funding relief for refugee healthcare. The first provinces to implement funding relief were Quebec and Manitoba, with Ontario following. Provincial politicians shared the human impact of the IFHP reforms illustrated through testimonies offered by healthcare workers and organizations working with newcomers. Healthcare professionals framed the IFHP reforms as irresponsible, unethical and harming the most vulnerable. Former Ontario Minister of Health, Deb Matthews, illustrated the importance of these stories when responding to criticism of her introduction of a funding relief program for refugees:

"The implementation of [the federal cuts] means that they have to say 'sorry, pregnant woman about to deliver baby, you're not covered, we're not going to care for you.' Do you really think our healthcare professionals will do that? Of course they will not, they should not, they cannot. So in the end, we were paying anyway but we were paying more than we would have had we provided better early care" (Morrow 2014).

New provincial refugee funding programs undermined the legitimacy of the federal government's measures to address bogus refugees and shifted refugee health coverage from a federal immigration venue to a provincial health venue. Concerned by this venue change, the newly appointed Minister of Citizenship and Immigration, Chris Alexander, challenged the policy authority of Ontario's decision and alluded to using the federal health transfer fund as a tool to enforce jurisdictional compliance:

"We [in the federal government] have respected their [provincial] political decisions including in healthcare, where we've given them 6 per cent [funding] escalators. We don't always agree with all of it, but we recognize that's provincial jurisdiction. This is a federal jurisdiction" (Wingrove 2014). 
The ensuing back-and-forth struggle for policy authority over refugee health coverage ultimately resulted in a policy vacuum, leaving the implementation of public policy up to individual providers and the actions of front-line workers.

\section{Searching for Decisional Authority: Venue of the Courts}

Amidst the provincial and federal struggle for power, a 2013 court case challenged the legality of the IFHP reforms. The Canadian Doctors for Refugee Care, Association of Refugee Lawyers and others issued a court challenge. They claimed that the changes to the IFHP violated a number of issues including charter and international law, a claim dismissed by Minister Kenney (Jones 2013). The ruling judge, Justice Mactavish, heard numerous examples of hardship resulting from the denial of medical insurance. For example, Justice Mactavish heard affidavits from six individuals who were forced to choose between food and life-saving medication (Mactavish 2014). After nearly a year in court, the policy changes were found unconstitutional and labelled a form of "cruel and unusual punishment" (Mactavish 2014). This decision, in which the government was denied a stay, ordered the reinstatement of funding to the IFHP. Despite the ruling being under appeal, the former federal government chose to wait until the final day of the court order before partially reinstating aspects of the IFHP (Vaughan 2015). This partial reinstatement resulted in a separate court trial to determine whether the government must fully reinstate funding to the IFHP (Vaughan 2015). In response to these court challenges, the Federal Minister's spokesperson Kevin Menard stated:

"Our government is defending the interests of Canadian taxpayers as well as the integrity of our refugee determination system. Regrettably, the Federal Court's ruling is costing taxpayers an extra \$4 million a year" (Keung 2015).

Menard's comments emphasized the interests of taxpayers and balancing the budget. The comments also avoided reference to bogus refugees, which deflected attention from Justice Mactavish's ruling and contradicted the moral theory that asylum-seekers were taking advantage of the health system. The focus on taxpayers and budget aligned with a timely, consistent pre-election message. The message tied into the federal party's 2015 campaign narrative that presented their party as the only party committed to cutting taxes, supporting

families and maintaining a strong economy (Conservative Party of Canada 2014). The legal system would ultimately provide the venue for reversing policy changes to the IFHP.

\section{The 2015 Election: A Change in Framing}

In the 2015 federal election, the three main political parties clearly outlined their positions on refugee health coverage. At the time, both the challenging parties publicly opposed the previous changes to the IFHP and committed to its funding reinstatement (Liberal Party of Canada 2014; New Democratic Party of Canada 2014). This was in contrast to the view 
of the former incumbent federal government; the party remained committed to maintain the IFHP reforms, and any original measures enacted for the purpose of "cracking down on human smuggling." The future of reforms to the IFHP was largely unclear until the 2015 election of a new majority Liberal Federal government. The new government changed the rhetoric of the IFHP by portraying refugee claimants, in particular Syrian refugees, as legitimately seeking asylum from war and conflict. The federal Liberal Government's decision to drop the previous federal Conservative Government's court appeal and announce a reinstatement of IFHP funding was met with praise and support from provincial Health Ministers (CBC 2016). The new federal Liberal Government's decision helped repair a fractured relationship with the provinces on healthcare and cost the federal government an estimated $\$ 5.9$ million annually (CBC 2016).

\section{Conclusion}

In this paper, we showed that policy decisions do not result from the collection and assessment of objective, balanced evidence alone; rather, these are highly political processes, framed and legitimized in strategic ways to move ideas into action. This paper used a set of policy concepts - agenda setting, framing, venues and causal stories, and applied these to a controversial policy issue in Canada: refugee healthcare funding. These concepts can be used to aid one's understanding of other policy issues and reforms (within and beyond the healthcare system). Both researchers and laypersons can use these concepts to critically appraise issues on the policy agenda and illuminate why issues become issues in the first place and why they are "solved" in particular ways. Most importantly, such an understanding of policy processes and outcomes has broader implications for effective citizen engagement and participation in the policy arena.

Correspondence may be directed to: Kerry Kuluski, MSW, PhD, Scientist, Lunenfeld Tanenbaum Research Institute, Sinai Health System, Assistant Professor, Institute of Health Policy, Management and Evaluation, University of Toronto, Toronto, ON; tel.: 416-461-8252 ×2988; e-mail:kerry.kuluski@sinaihealthsystem.ca.

\section{References}

Barnes, S. 2012. The Real Costs of Cutting Refugee Health Benefits: A Health Equity Impact Assessment. Toronto, ON: Wellesley Institute.

Bay Observer Staff. 2015. Hamilton Healthcare Providers Refuse to Cooperate with Refugee Health Cuts. Retrieved May 20, 2015. <http://bayobserver.ca/hamilton-healthcare-providers-refuse-to-cooperate-with-refugee-health-cuts/>. Beaudoin, J., J. Danch and S. Reehag. 2015. "No Refuge: Hungarian Romani Refugee Claimants in Canada." Osgoode Hall Law Journal 11(3).

Boesveld, S. 2015. Efforts to Keep Bogus Roma Refugees Out Have Failed: Jason Kenney. Retrieved March 1, 2015. $<$ http://news.nationalpost.com/news/efforts-to-keep-bogus-roma-refugees-out-have-failed-jason-kenney/>.

Bowman, A. 2014. "Policy Implementation." In Encyclopedia of Public Administration and Public Policy (2nd ed., Vols. 1-3, pp. 37-41). Columbia, SC: Department of Government and International Studies. doi:10.1081/E-EPAP2-120011068. 
Canadian Broadcasting Corporation (CBC). 2010. Tamil Ship Could Lead to Law Change: Harper. Retrieved May 20, 2003. <http://www.cbc.ca/news/canada/story/2010/08/17/harper-tamil-migrants.html>

Canadian Broadcasting Corporation (CBC). 2016. Liberal Government Fully Restores Refugee Health Care Program. Retrieved February 18, 2016. <http://www.cbc.ca/news/politics/mcallum-philpott-interim-federalhealth-program-refugees-1.3453397>.

Canadian Border Services Agency. 2012. Project SARA. International and Domestic Activities Final Report. Ottawa, ON: Government of Canada.

Citizenship and Immigration Canada. 2015. Minister Kenney Issues Statement on the Passage of the Journey to Freedom Day Act. Retrieved May 20, 2005. <http://news.gc.ca/web/article-en.do?nid=966489>.

Conservative Party of Canada. 2014. Where We Stand. Retrieved April 1, 2015. <http://www.conservative.ca/ where-we-stand/>.

Crynes, D. 1998. Venue and Image Change: The Judicial Role in Systemic and Formal Agenda Setting. Kansas City, MO: University of Kansas.

Government of Canada. 2012a. Archived - Reform of the Interim Federal Health Program Ensures Fairness, Protects Public Health and Safety. Retrieved June 1, 2016. <http://news.gc.ca/web/article-en.do?nid=670949>.

Government of Canada. 2012b. Backgrounder - Summary of Changes to Canada's Refugee System in Protecting Canada's Immigration System Act. Retrieved June 1, 2016. <http://www.cic.gc.ca/english/department/media/ backgrounders/2012/2012-02-16f.asp >.

Government of Canada. 2012c. New Measures to Crack Down on Human Smuggling. Retrieved March 1, 2015. $<$ http://www.cic.gc.ca/english/refugees/reform-smuggling.asp $>$.

Government of Canada. 2015. Audit of the Control Framework for the Interim Federal Health Program. Retrieved April 1, 2015. <http://www.cic.gc.ca/english/resources/audit/ifh.asp>.

Government of Canada. 2016. Refugee Claims. Retrieved January 7, 2017. <http://open.canada.ca/data/en/ dataset/8a136ac4-951b-43fe-bac9-15d5b71a6f5c >.

Green-Pedersen, C. and S. Walgrave. 2014. Agenda Setting, Policies, and Political Systems: A Comparative Approach. Chicago, IL: University of Chicago Press.

Jones, A. 2013. Doctors' Group takes Ottawa to Court over Refugee Health-Care Cuts. Retrieved April 1, 2015. $<$ http://www.theglobeandmail.com/news/politics/doctors-group-takes-ottawa-to-court-over-refugee-health-care-cuts/ article $9047552 />$.

Jordan, J. and A. Turnpenny. 2015. The Tools of Policy Formation: Actors, Capacities, Venues and Effects. Northampton, MA: Edward Elgar Publishing.

Keung, N. 2012. Canadian Doctors, Nurses Join Protest against Cuts to Refugee Health Plan. Retrieved March 1, 2015. <http://www.thestar.com/news/gta/2012/05/23/canadian_doctors_nurses_join_protest_against_cuts_ to_refugee_health_plan.html>.

Keung, N. 2013. Ontario Hospitals Absorb Health Costs to Treat Refugees. Retrieved March 1, 2015. <http://read. thestar.com/?origref=\#!/article/51b3ad377bleac518d1b99b5-ontario-hospitals-absorb-health-costs-to-treatrefugees $>$.

Keung, N. 2015. Ottawa Spent \$1.4M in Court to Fight for Refugee Health Cuts. Retrieved April 1, 2015.<http:// www.thestar.com/news/immigration/2015/01/28/ottawa-spent-14m-in-court-to-fight-for-refugee-health-cuts.html>.

Liberal Party of Canada. 2014. Call on Harper to Restore Refugee Health Care. Retrieved May April 1, 2015. $<$ http://petition.liberal.ca/call-harper-restore-refugee-health-care/>.

Mactavish, J. 2014. Federal Court of Appeal Between: Attorney General of Canada and Minister of Citizenship and Immigration and Canadian Doctors for Refugee Care, The Canadian Association of Refugee Lawyers, Daniel Garcia Rodriques, Hanif Ayubi and Justice for Children and Youth and Registered Nurses Association of Ontario and Canadian Association of Community Health Centres. Retrieved May 16, 2017. <http://cas-cdc-www02.cas-satj. gc.ca/rss/T-356-13\%20Cdn\%20Doctors\%20v\%20AGC\%20Judgment\%20and\%20Reasons.pdf>.

McCombs, M. and A. Reynolds. 2002. “News Influence on our Pictures of the World." In J.B.a.D. Zillmann (Ed.), Media Effects: Advances in Theory and Research (pp. 1-18). Mahwah, NJ: Lawrence Erlbaum Associates, Inc. 
Morrow, A. 2014. Cutting Health Care for Refugee Claimants Expensive in Long-run, Ont. Health Minister Says. Retrieved March 1, 2015. <http://www.theglobeandmail.com/news/politics/ cutting-health-care-for-refugee-claimants-expensive-in-long-run-ont-health-minister-says/article16502436/>.

New Democratic Party of Canada. 2014. NDP calls on Conservatives to Restore Health Care for Vulnerable Refugees. Retrieved April 1, 2015. <http://www.ndp.ca/news/ndp-calls-conservatives-to-restore-health-care-vulnerable-refugees>.

Parry, T. 2015. Doctors Vow to Track Impact of Refugee Health Cuts. Retrieved May 20, 2013. <http://www.cbc. $\mathrm{ca} / \mathrm{m} /$ touch/politics/story/1.1168265>.

Stone, D. 1989. “Causal Stories and the Formation of Policy Agendas." Political Science Quarterly 104(2): 281-300.

United Nations High Commission for Refugees. 2015. Asylum Seekers. Retrieved May 20, 2003. <http://www. unhcr.org/pages/49c3646c137.html>.

Vaughan, A. 2015. Refugee Health Advocates Return to Court, Pushing Feds to Comply Four Months to Fix Ended in November. Radio-Canada. Retrieved April 1, 2015. <http://www.ndp.ca/news/ ndp-calls-conservatives-to-restore-health-care-vulnerable-refugees $>$.

Wherry, A. 2012. Bogus Refugee Claimants Receiving Gold-Plated Health Care Benefits. Retrieved March 1, 2015. $<$ http://www.macleans.ca/politics/ottawa/bogus-refugee-claimants-receiving-gold-plated-health-care-benefits/>. Wingrove, J. 2014. Ontario "Wrong” on Refugee Health Care, Immigration Minister Says. Retrieved May 20, 2015. $<$ http://www.theglobeandmail.com/news/politics/ontario-wrong-on-refugee-health-care-immigration-minister-says/ article16479008/>.

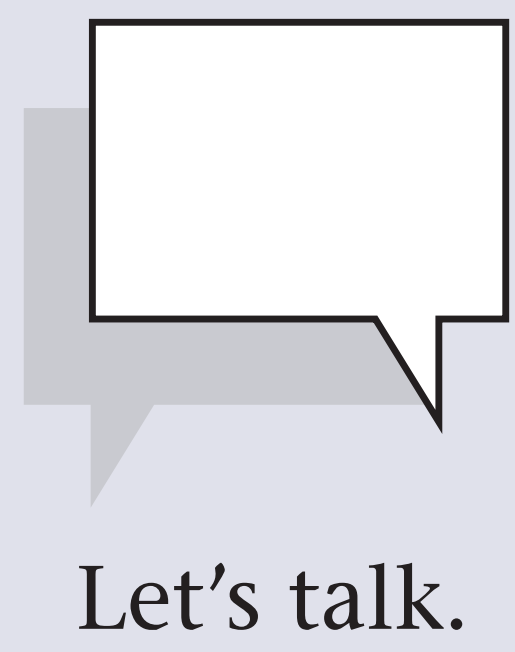

Longwoods.com

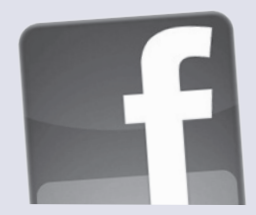

